\title{
Moral Consensus in Bioethics: Illusive or Just Elusive?
}

\author{
GRIFFIN TROTTER
}

This issue of $C Q$ was conceived in Salt Lake City, at the third annual meeting of the American Society of Bioethics and Humanities (ASBH). There, Presidentelect Laurie Zoloth delivered a stirring address, emphasizing the role of bioethics in responding to social deprivations and suggesting that ASBH "take a stand" on important issues where members share consensus. Not all the stirrings were pleasant. Debate erupted about the propriety of consensus statements, especially regarding possible deleterious effects on academic discourse, misappropriation of dues, and the proliferation of quasi-political factions. The roots of this controversy extend deeply into the collective psyche of contemporary bioethics.

Perhaps the most conspicuous theme of twentieth-century intellectual history was the observation that moral values are historically and culturally contingent, and hence irremediably plural. Moral pathologists classified this insight as the Enlightenment's fatal malignancy, yet it blossomed into a decorous postmodern tradition. Its legacy is a paradox that will be facing us for many years. Moral pluralism, initially viewed as a value-neutral, unintended byproduct of contingency, has transmogrified into ethics' guiding value-the new telos for nonteleological society. Bereft of other options, many bioethicists now cite pluralism as the name of the good. On this pretext, we busy ourselves spinning off a plurality of freestanding, incompatible, and sometimes mutually intolerant pluralisms. ${ }^{1}$

This paradox is exacerbated by the persistence of nonpostmodern moral traditions that do not recognize the intrinsic goodness of pluralism. More distressingly, there is no guarantee that if left largely to their own resources (as presumably they would be in broader pluralistic settings) these wayward traditions will ever come around. The problem, then, is that moral pluralism, as a candidate for a universal moral standard, seems to be self-defeating. It can be achieved only by suppressing alternative moral visions. Where, then, will we find enough moral common ground to facilitate social progress?

Into this breach the discipline of bioethics has leapt with a vengeance. Two basic responses, each reflecting a sort of transvaluation of pluralism along with other dominant Western values, seem to have emerged. Each response has several variations, and many are present in the current issue. On one hand, we have thinkers who interpret pluralism through the lens of equality. Here the ideal is to maximize life opportunities for all people and to create a secure environment in which individuals and communities can pursue cooperative ideals harmoniously and safely. This version posits a consensus-oriented meth- 
odology. On the other hand are thinkers who emphasize competition and the strife of ideas and traditions. This libertarian vision represents pluralism as a disavowal of secular priesthoods and coercive oversight, and leaves moral communities largely to their own resources. It prescribes permission or consentrather than consensus - as the ruling norm in public life.

To understand these variations it is perhaps useful to construct a model bioethical economy. On the supply side we have bioethicists themselves, infusing inquiry with technical procedural values and bioethicists' personal worldviews. Insofar as bioethics is a specialized form of inquiry and bioethicists are a unique demographic group, we should expect a degree of idiosyncrasy. Do bioethicists gravitate, as Engelhardt has alleged, toward the political left? Are rituals of discourse privileged over carnal regimens and faithful rites? For now, any response to such queries will pivot on individual perceptions. There is, alas, little data about bioethicists' personal biases.

From the perspective of demand there is more to go on. Bioethics emerged as medical technology became more potent, dangerous, expensive, elusive, and novel. ${ }^{2}$ Professional values-previously bestowed by a trusted medical community-were no longer sufficient to quell public anxiety. Nor was there state religion or any other independent moral authority to offer satisfactory solutions. Bioethics offered itself as a source of moral expertise or, at least, as a neutral space for resolving moral dilemmas and controversies. In response, society created academic departments, ethics committees, government commissions, and so forth. Demand increased and bioethics grew.

This is, of course, a familiar narrative, and I will not attempt to supplement or improve it here. What may be helpful by way of introduction to this volume is the observation that our two schools of thought - the roughly egalitarian and the roughly libertarian - seem to be responding in different ways to the "demand side" economy of bioethics. The egalitarian-minded thinkers in this issue are keen to fill the public void. Micah Hester leans heavily on John Dewey, Mark Kuczewski cites the casuists, and Zoloth draws from her background in Jewish ethics. But each is spurred by a similar array of concrete urgencies. Blushing at the practical limitations of naked postmodernism, these thinkers want to redress the movement, clothing it in all-weather, action-ready cosmopolitanism. Consensus-viewed here more as a process or procedure than as a static outcome-is the means by which they intend to negotiate public policy and carry out the arduous process of mutual self-discovery. Unsurprisingly, given the leftward locus of bioethical "demand," these thinkers sow consensus by privileging the egalitarian perspective over libertarian variants. Hence, both Kuczewski and Zoloth suggest that practically everyone in bioethics believes that (in Kuczewski's words) "any serious attempt to provide health insurance to all our citizens is morally preferable to the current system."

But libertarians - even lukewarm ones - think there are a number of possible scenarios in which serious attempts to provide health insurance beget outcomes worse than the current system. They are skeptical of claims that bioethics can provide moral authority for reforming medical services and research, and hence they are less enthusiastic about meeting the demand for consensus. Of course, libertarians' lassitude about consensus development may also reflect their proximity to the political right, a realm where bioethical consultations, commissioning, and community building have yet to reach their stride. Though disagreeing on important methodological issues, H. Tristram Engelhardt and 


\section{Guest Editorial}

Griffin Trotter hoist the libertarian banner in this issue. Unlike many traditional libertarians, these thinkers recognize the primacy of moral communities (visà-vis unencumbered individuals) in the genesis of moral values. Their libertarianism consists largely in acknowledging refractory incongruities that distinguish various moral communities, and in insisting that communities remain free to chart their own moral destinies. For Engelhardt, these incongruities imply that citizens from diverging communities will be moral strangers. Invoking the moderate American Whig tradition, Trotter perceives an intermediate condition where important overlapping values exist, but not to a degree that potentiates robust consensus about contentious issues in bioethics. ${ }^{3}$

Rounding out the issue is an invited reply from Jonathan Moreno, arguably the guru of consensus-oriented bioethics. Professor Moreno penned the first definitive treatise on the issue back in $1995,{ }^{4}$ precipitating much of the current debate. Now, for the time being, Moreno also gets the last word.

\section{Notes}

1. Zoloth L. Health Care and the Ethics of Encounter: A Jewish Discussion of Social Justice. Chapel Hill: University of North Carolina Press, 1999:20. Zoloth observes that we function in "an academic and public arena that is theoretically deeply committed to pluralism and that attempts to name 'the good' with a standard that can be jointly used."

2. Jonsen A. The Birth of Bioethics. New York: Oxford University Press, 1998.

3. Kevin Wildes adroitly develops an intermediate category - "moral acquaintances" - that bridges the gap between strangers portrayed by Engelhardt and friends portrayed by consensusoriented bioethicists. See his Moral Acquaintances: Methodology in Bioethics. Notre Dame, Ind.: University of Notre Dame Press, 2000.

4. Moreno JD. Deciding Together: Bioethics and Moral Consensus. New York: Oxford University Press, 1995. 